\title{
VITAMIN D RECEPTOR (FOKI, BSMI AND TAQI) GENE POLYMORPHISMS AND TYPE 2 DIABETES MELLITUS: A NORTH INDIAN STUDY
}

\author{
HEMANT KUMAR BID, RITURAJ KONWAR, C. G. AGGARWAL'1, SUNAINA GAUTAM², \\ MADHUKAR SAXENA ${ }^{2}$, V. LAKSHMA NAYAK, MONISHA BANERJEE ${ }^{2}$
}

ABSTRACT

BACKGROUND: The vitamin D receptor (VDR) gene is a candidate gene for susceptibility to several diseases. Studies on association between VDR polymorphisms and risk of type 2 diabetes (T2DM) in different ethnic populations are yet inconclusive. AIMS: This study was conducted to evaluate association between VDR polymorphisms and genetic susceptibility to T2DM in the north Indian population. SETTING AND DESIGN: One hundred clinically diagnosed T2DM patients and 160 healthy controls from the north Indian population were recruited for genetic association study. MATERIALS AND METHODS: Genomic DNA was extracted from blood and genotyped for the single nucleotide polymorphism SNPs of Fokl (T/C) [rs2228570], Bsml (A/G) [rs1544410] and Taql (C/T) [rs731236] by polymerase chain reaction and restriction fragment length polymorphism (PCR-RFLP) analysis. STATISTICAL ANALYSIS USED: Genotype distribution and allelic frequencies were compared between patients and controls. Mean values and odds ratios (ORs) with 95\% confidence interval (CI) were calculated using SPSS software (version 15.0). RESULTS: The genotype distribution, allele and haplotype frequencies of VDR polymorphism did not differ significantly between patients and controls. Mean age and waist-hip ratio of patients were found to be associated with VDR polymorphism. Combination studies showed FFBbtt increased the risk of T2DM in north Indians. CONCLUSIONS: Our data suggest that VDR gene polymorphism in combination of genotypes is associated with the risk of T2DM and thus requires further studies as a probable genetic risk marker for T2DM.

Key words: Diabetes, genetic polymorphisms, restriction fragment length polymorphisms, vitamin $D$ receptor

DOI: $10.4103 / 0019-5359.53164$

Endocrinology Division, CDRI, Lucknow, 'Department of Medicine, Chhatrapati Sahuji Maharaj Medical University, Lucknow, ${ }^{2}$ Department of Zoology, University of Lucknow, India

Correspondence:

Dr. Monisha Banerjee

Molecular and Human Genetics Laboratory,

Department of Zoology, University of Lucknow,

Lucknow - 226 007, India

E-mail: banerjee_monisha30@ rediffmail.com

\section{INTRODUCTION}

Environmental and genetic factors play important roles in the mechanisms involved in the development of T2DM. Studies on genes inducing susceptibility to T2DM have been carried out by various groups in different 
populations. ${ }^{[1-9]}$ An association study of candidate genes, viz., fatty acid binding protein 2 (FABP2), uncoupling protein type 1 gene (UCP1), protein phosphatase type 1 (PP1G), $\beta 3$ adrenergic receptor $(\beta 3 A R), V D R$, was carried out on T2DM patients in a migrant Indian population as well by Boullus-Sanchis et al. ${ }^{[10]}$

Genome-wide association studies have led to the identification of several single nucleotide polymorphisms in genes such as CDKAL1, CDKN2B, HHEX/IDE, IGF2BP2, KCNJ11, SLC30A8, TCF2, TCF7L2 and WFS1.[11] Several genes were studied but only a handful showed confirmed association, such as resistin, alpha-endosulfine, calpain 10, peroxisome proliferators-activated receptor-gamma 2 (PPAR $\gamma-2)$, abundant transcript 1 gene (apM1), TCF7L2, insulin-like growth factor-binding protein 5 (IGFBP5), to name a few. ${ }^{[9,12-19]}$

Earlier studies on genetic polymorphisms in T2DM candidate genes were carried out among south Indians, in addition to those in the VDR gene. ${ }^{[20-22]}$ VDR is a member of the steroid/thyroid hormone receptor family. ${ }^{[23]}$ It is known that vitamin $D$ and especially its activated metabolite 1,25-dihydroxyvitamin D3 $(1,25 \mathrm{D} 3)$ are involved in controlling the normal functions of the endocrine pancreas, particularly insulin secretion; and the action of vitamin $D$ is mediated through binding to its nuclear receptor (VDR). ${ }^{[24]}$ Vitamin $D$ and its receptor complex play the role of a transcription factor in regulating the $\beta$-cell insulin secretion. Vitamin-D deficiency has been shown to impair insulin synthesis and secretion in humans and in animal models of diabetes, which suggests it has a role in the development of type 2 diabetes. ${ }^{[25]}$ There is evidence to suggest that altered vitamin $\mathrm{D}$ and calcium homeostasis also play a role in the development of T2DM; and recently, Knekt et al. reported that high vitamin D status provides protection against type 2 diabetes. ${ }^{[26-27]}$

In recent years, several polymorphisms, such as Bsml and Fokl, have been described in the VDR genes that are able to alter the activity of VDR protein. ${ }^{[28]}$ Some of the other polymorphisms in the VDR gene identified by allelic variation in restriction enzyme sites are Tru9l, Taql, EcoRV and Apal. ${ }^{[29]}$ All these are located between exons 8 and 9 except that Fokl is in exon 2. Fokl polymorphism has been shown to have functional role in trascriptional activation of $V D R$ gene. ${ }^{[30]}$ However, the genetic background of the disease still remains unclear. Although these findings suggest that the VDR gene is a novel candidate gene contributing to susceptibility to T2DM [Table 1], there are no data on association of VDR gene polymorphism with T2DM in the north Indian population. In our present work, we studied the Fokl, Bsml and Taql restriction enzyme polymorphisms of the VDR gene in patients with T2DM in a north Indian population.

\section{MATERIALS AND METHODS}

\section{Subject selection}

The current study was carried out after obtaining prior approval from the institutional ethical committee of Chhatrapati Sahuji Maharaj Medical University (CSMMU), Lucknow, India. Patients $(n=100)$ with type 2 diabetes attending the Diabetes Clinic in the outpatient department of CSMMU, Lucknow, were enrolled for the present study. 
Table 1: Data of genetic polymorphisms of VDR gene and T2DM risk from different countries

\begin{tabular}{|c|c|c|c|c|c|}
\hline VDR site & T2D patients & Mean age & Association & Country & Reference \\
\hline $\begin{array}{l}\text { Intron } 8 \text { (Bsml, Tru9l, Apal) } \\
\text { and exon } 9 \text { (Taql) }\end{array}$ & 309 & $62+12$ & NS & France & Ye et $a^{\left[{ }^{[36]}\right.}$ \\
\hline Bsml & 293 & NA & $\mathrm{s}$ & Germany & Ortlepp et al [37] \\
\hline Apal, Bsml, Taql & 242 & $71.7+8.6$ & NS & San Diego, & Oh et al ${ }^{[38]}$ \\
\hline Bsml & 49 & $57(29-77)$ & NS & Hungry & Speer et al [23] \\
\hline Fokl, Bsml, Apal and Taql & 267 & $50.0 \pm 9.2$ & NS & Poland & Cyganek et al [39] \\
\hline Apal, Bsml and Taql & 164 & $45.9 \pm 10.3$ & $\begin{array}{c}\text { S (Apal) } \\
\text { NS (Bsml and Taql) }\end{array}$ & Bangladeshi Asians & Hitman et al [22] \\
\hline Fokl, Bsml and Taql & 100 & $49.32 \pm 10.97$ & NS & North India & Our study \\
\hline
\end{tabular}

$\mathrm{S}=$ significant; $\mathrm{NS}=$ nonsignificant, VDR: vitamin $\mathrm{D}$ receptor

Screening and management of patients were done as per American Diabetes Association guidelines. ${ }^{\left[{ }^{[1]}\right.} \mathrm{A}$ questionnaire was used to record clinical history of patients, family history of diabetes and associated complications such as hypertension, etc.

A total of 160 age- and sex-matched normal healthy controls were enrolled for the study from among the healthy staff members of the institute and the university. They were screened with standard oral glucose tolerance test. Subjects having a history of coronary artery disease and other complications were not included in the control group.

\section{DNA extraction and genotyping}

After obtaining an informed consent, $5 \mathrm{~mL}$ of blood sample was collected in anticoagulant and plain vials from patients of both the groups. DNA was extracted from the blood samples by using QIAamp DNA mini kit (QIAGEN, Germany). Amplification was performed in a 20$\mu \mathrm{L}$ reaction mixture containing genomic DNA (100-150 ng), 200 nM dNTPs (MBI-Fermentas, USA), 2-8 pmol of each primer and 0.5U of Taq DNA polymerase (MBI-Fermentas, USA) per tube in a gradient thermal Master cycler (Eppendorf, USA). Amplification reactions were set up separately for Fokl, Bsml and Taql polymorphic sites of $V D R$ gene using primers given by Harris et al. and Morrison et al. [Table 2]. ${ }^{[32-33]}$ PCR-RFLP was used to identify the genotypic pattern of VDR family.

In order to improve the genotyping quality and validation, $20 \%$ of samples were re-genotyped by other laboratory personnel, and results were found to be reproducible with no discrepancy in genotyping. Genotyping of $10 \%$ randomly selected samples was confirmed by DNA sequencing.

Table 2: PCR-RFLP pattern of Fokl, Bsml and Taql polymorphisms of vitamin D receptor gene

\begin{tabular}{|c|c|c|c|}
\hline Polymorphisms & Primers & $\begin{array}{l}\text { Annealing } \\
\text { Temp ( } \mathrm{C})\end{array}$ & $\begin{array}{c}\text { PCR-RFLP } \\
\text { products (bp) }\end{array}$ \\
\hline $\begin{array}{l}\text { Exon } 2(\mathrm{~T} / \mathrm{C}) \\
\text { Fokl } \\
\text { rs2228570 }\end{array}$ & $\begin{array}{l}\text { F 5'- AGC TGG CCC TGG CAC TGA CTC TGC TCT - 3' } \\
\text { R 5'- ATG GAA ACA CCT TGC TTC TTC TCC CTC - 3' }\end{array}$ & 58 & $\begin{array}{l}\text { (TT) FF/ 196, } 69 \\
\text { (TC) Ff/265, 196, } 69 \\
\text { (CC) } \mathrm{ff} / 265\end{array}$ \\
\hline Exon $7 /$ Intron 8 (A/G) & F 5'- CAA CCA AGA CTA CAA GTA CCG CGT CAG TGA - 3' & 63 & (GG) BB/650,175 \\
\hline & R 5'- AAC CAG CGG GAA GAG GTC AAG GG - 3' & & $\begin{array}{l}\text { (GA) Bb/825,650,175 } \\
\text { (AA) bb/825 }\end{array}$ \\
\hline $\begin{array}{l}\text { Exon 9, codon } 352 \\
(\mathrm{C} / \mathrm{T}) \text { Taql }\end{array}$ & F 5'-CAG AGC ATG GAC AGG GAG CAA-3' & 63 & (TT) TT/495,245 \\
\hline rs731236 & R 5'-GCA ACT CCT CAT GGC TGA GGT CTC-3' & & $\begin{array}{l}\text { (TC)Tt/495,290,245,205 } \\
\text { (CC) } t \mathrm{tt} / 290,245,205\end{array}$ \\
\hline
\end{tabular}

PCR-RFLP = polymerase chain reaction and restriction fragment length polymorphism 


\section{Statistical analysis}

Allele frequencies, genotype frequencies and carriage rates of the alleles in all the groups were compared by using Fisher's exact test. The Hardy-Weinberg equilibrium at individual loci was assessed by $\chi^{2}$ statistics using SPSS software (version 15.0), and clinical association was calculated by paired $t$ test. All $P$ values were two sided, and differences were considered statistically significant for $P<0.05$. Odds ratio (OR) at $95 \%$ confidence interval $(\mathrm{Cl})$ was determined to describe the strength of association by logistic regression model. Allele frequency was calculated as the number of occurrences of the test allele in the population divided by the total number of alleles. Carriage rate was calculated as the number of individuals carrying at least one copy of test allele divided by the total number of individuals.

\section{RESULTS}

Clinical characteristics of the patients are summarized in Table 3. The average age of the patient population was $49.32 \pm 10.97$ years, with mean BMl of $24.26 \pm 4.30 \mathrm{~kg} / \mathrm{m}^{2}$. The allele and genotype frequency distribution and carriage rate of VDR (Fokl, Bsml and Taql) genes among patients and controls were as shown in Table 4. We did not observe any significant difference in VDR (Fokl, Bsml and Taql) genotypes between patient and control groups ( $P=0.119,0.428$ and 0.416 , respectively). Genotypes of each VDR marker were in HardyWeinberg equilibrium in each group separately and in the total of 100 T2DM patients.

Table 3: Clinical characteristics of patients with T2DM

\begin{tabular}{lc}
\hline No. of patients & 100 \\
\hline Age (years) & $49.32 \pm 10.97$ \\
Duration of diabetes (years) & $5.00 \pm 5.70$ \\
BMI (kg/m²) & $24.26 \pm 4.30$ \\
WHR (waist-hip ratio) & $1.03 \pm 0.90$ \\
Fasting plasma glucose (mg/dL) & $174.30 \pm 79.44$ \\
Postprandial plasma glucose (mg/dL) & $264.50 \pm 102.90$ \\
Total cholesterol (mg/dL) & $225.13 \pm 33.10$ \\
LDL cholesterol (mg/dL) & $160.80 \pm 30.41$ \\
HDL cholesterol (mg/dL) & $42.60 \pm 3.50$ \\
VLDL cholesterol (mg/dL) & $23.31 \pm 3.80$ \\
Triglyceride (mg/dL) & $115.00 \pm 14.10$ \\
Blood pressure (systolic) (mm Hg) & $131.40 \pm 15.25$ \\
Blood pressure (diastolic) (mm Hg) & $81.44 \pm 10.70$ \\
Serum creatinine (mg/dL) & $1.04 \pm 0.97$ \\
\hline
\end{tabular}

Data are mean \pm standard deviation (SD) or frequencies (\%).

Table 4: Distribution of genotype, allele frequencies and carriage rate of VDR (Fokl, Bsml and Taql) among patients and controls

\begin{tabular}{|c|c|c|c|c|c|c|c|c|c|c|c|c|}
\hline \multirow[t]{2}{*}{ Genotype } & \multicolumn{3}{|c|}{ Fokl } & \multirow[t]{2}{*}{$P$ value } & \multicolumn{3}{|c|}{ Taql } & \multirow[t]{2}{*}{$P$ value } & \multicolumn{3}{|c|}{ Bsml } & \multirow[t]{2}{*}{$P$ value } \\
\hline & $\begin{array}{l}F F \\
(\%)\end{array}$ & $\begin{array}{l}F F \\
(\%)\end{array}$ & $\begin{array}{c}f f \\
(\%)\end{array}$ & & $\begin{array}{l}T T \\
(\%)\end{array}$ & $\begin{array}{c}T t \\
(\%)\end{array}$ & $\begin{array}{c}t t \\
(\%)\end{array}$ & & $\begin{array}{l}B B \\
(\%)\end{array}$ & $\begin{array}{l}B b \\
(\%)\end{array}$ & $\begin{array}{l}b b \\
(\%)\end{array}$ & \\
\hline $\begin{array}{l}\text { Patients } \\
(100)\end{array}$ & $\begin{array}{c}38 \\
(38.0)\end{array}$ & $\begin{array}{c}60 \\
(60.0)\end{array}$ & $\begin{array}{c}2 \\
(2.0)\end{array}$ & 0.119 & $\begin{array}{c}36 \\
(36.0)\end{array}$ & $\begin{array}{c}49 \\
(49.0)\end{array}$ & $\begin{array}{c}15 \\
(15.0)\end{array}$ & 0.416 & $\begin{array}{c}30 \\
(30.0)\end{array}$ & $\begin{array}{c}52 \\
(52.0)\end{array}$ & $\begin{array}{c}18 \\
(18.0)\end{array}$ & 0.428 \\
\hline & $\begin{array}{c}80 \\
(50.0)\end{array}$ & $\begin{array}{c}79 \\
(49.4)\end{array}$ & $\begin{array}{c}1 \\
(0.63)\end{array}$ & & $\begin{array}{c}67 \\
(41.87)\end{array}$ & $\begin{array}{c}65 \\
(40.63)\end{array}$ & $\begin{array}{c}28 \\
(17.5)\end{array}$ & & $\begin{array}{c}60 \\
(37.5)\end{array}$ & $\begin{array}{c}77 \\
(47.13)\end{array}$ & $\begin{array}{c}23 \\
(14.38)\end{array}$ & \\
\hline \multicolumn{13}{|c|}{ Allele frequency } \\
\hline $\begin{array}{l}\text { Patients } \\
(100)\end{array}$ & $\begin{array}{c}136 \\
(68.0)\end{array}$ & $\begin{array}{c}64 \\
(32.0)\end{array}$ & \multirow[t]{2}{*}{$\begin{array}{c}1.0 \text { (Ref) } \\
0.720 \\
(0.488-1.063)\end{array}$} & 0.098 & $\begin{array}{c}121 \\
(60.5)\end{array}$ & $\begin{array}{c}79 \\
(39.5)\end{array}$ & \multirow[t]{2}{*}{$\begin{array}{c}1.0 \text { (Ref) } \\
0.931 \\
(0.648-1.338)\end{array}$} & 0.700 & $\begin{array}{c}112 \\
(56.0)\end{array}$ & $\begin{array}{c}88 \\
(44.0)\end{array}$ & \multirow[t]{2}{*}{$\begin{array}{c}1.0 \text { (Ref) } \\
0.795 \\
(0.555-1.138)\end{array}$} & \multirow[t]{2}{*}{0.209} \\
\hline $\begin{array}{l}\text { Controls } \\
(160) \\
\text { Carriage r }\end{array}$ & $\begin{array}{l}239 \\
(74.7) \\
\text { ate }\end{array}$ & $\begin{array}{c}81 \\
(25.3)\end{array}$ & & & $\begin{array}{c}199 \\
(62.2)\end{array}$ & $\begin{array}{c}121 \\
(37.8)\end{array}$ & & & $\begin{array}{c}197 \\
(61.57)\end{array}$ & $\begin{array}{c}123 \\
(38.43)\end{array}$ & & \\
\hline $\begin{array}{l}\text { Patients } \\
\text { (100) }\end{array}$ & $\begin{array}{c}98 \\
(98.0)\end{array}$ & $\begin{array}{c}62 \\
(62.0)\end{array}$ & \multirow[t]{2}{*}{$\begin{array}{c}1.0 \text { (Ref) } \\
0.795 \\
(0.524-1.206)\end{array}$} & 0.281 & $\begin{array}{c}85 \\
(85.0)\end{array}$ & $\begin{array}{c}64 \\
(64.0)\end{array}$ & \multirow[t]{2}{*}{$\begin{array}{c}1.0 \text { (Ref) } \\
0.798 \\
(0.531-1.201)\end{array}$} & 0.280 & $\begin{array}{c}82 \\
(82.0)\end{array}$ & $\begin{array}{c}70 \\
(70.0)\end{array}$ & \multirow[t]{2}{*}{$\begin{array}{c}1.0 \text { (Ref) } \\
0.981 \\
(6.652-1.475)\end{array}$} & 0.926 \\
\hline $\begin{array}{l}\text { Controls } \\
(160)\end{array}$ & $\begin{array}{c}159 \\
(99.37)\end{array}$ & $\begin{array}{c}80 \\
(50.0)\end{array}$ & & & $\begin{array}{c}132 \\
(82.5)\end{array}$ & $\begin{array}{c}93 \\
(58.13)\end{array}$ & & & $\begin{array}{c}137 \\
(86.0)\end{array}$ & $\begin{array}{c}100 \\
(62.5)\end{array}$ & & \\
\hline
\end{tabular}


In addition, we also compared the VDR (Fokl, Bsml and Taql) genotypes with different clinical parameters of T2DM but could not obtain association of any of the parameters except age $(P=0.002)$ and waist-hip ratio $(P=0.013)$ with VDR Taql genotypes [Table 5].

Combining Fokl, Bsml and Taql genotypes resulted in 23 possible combinations. When each combination genotype was tested using $X 2$ against all other combination genotypes, there was a trend of increased risk of diabetes in the genotypes FfBbTt $\{P=0.136, \mathrm{OR}=4.00$ (0.64-24.69) $\}$ and FFBbtt $\{P=0.334, \mathrm{OR}=2.50$ (0.38-16.04)\}.

\section{DISCUSSION}

Allelic differences in the VDR gene may contribute to the genetic predisposition to certain diseases. As vitamin $D$ modulates insulin secretion, it is feasible that genetic variants of the VDR gene may contribute to the development of T2DM. Since patients with T2DM exhibit subtle alterations in glucose metabolism long before onset of the disease, genetic factors contributing to its pathogenesis or development could be detected early in the disease process. ${ }^{[34]}$

Our study revealed significant association of age $(P=0.002)$ and waist-hip ratio $(P=0.013)$ with Taql genotypes of $V D R$ gene polymorphism. This may indicate the association of VDR polymorphism with both modifiable and nonmodifiable risk factors of diabetes.

Our investigation showed the nonsignificant association between VDR (Fokl, Bsml and Taql) genotypes and diabetes risk in the north

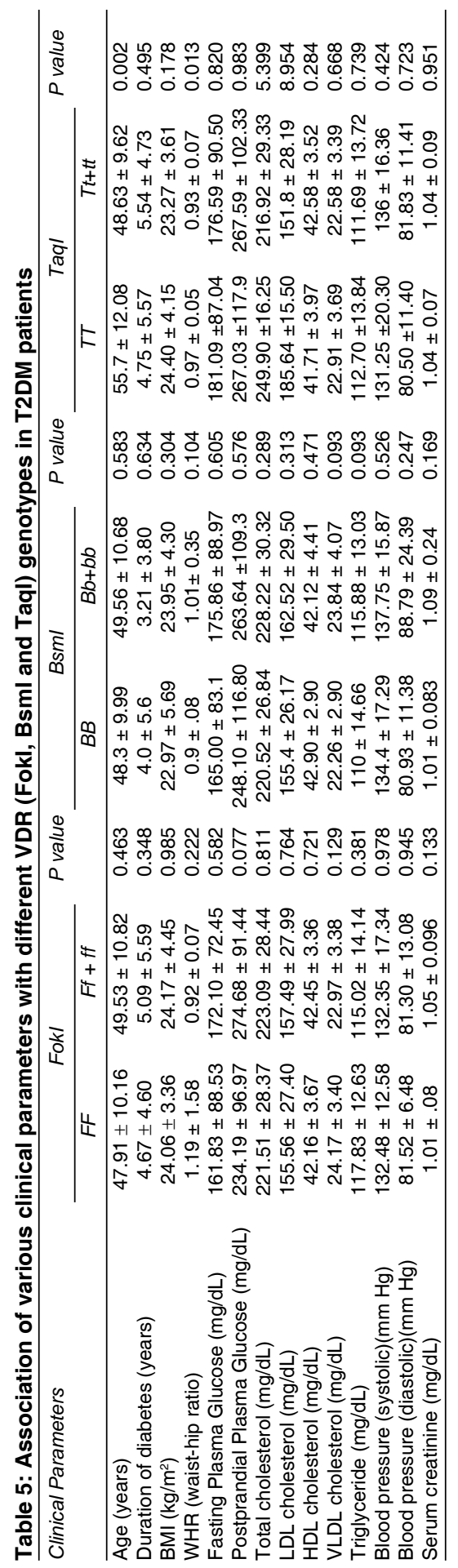

Indian J Med Sci, Vol. 63, No. 5, May 2009 
Indian population. Previous investigations of $V D R$ polymorphisms and diabetes risk by other groups have produced inconsistent results [Table 1].

Two studies have reported link between $V D R$ polymorphism and diabetes risk - one in Caucasian subjects, for Bsml site; and the other in Bangladeshi Asians, for Apal site. ${ }^{[23]}$ However, our study, like the one in Polish population, showed no association between VDR Fokl, Apal, Bsml and Taql polymorphism and diabetes risk. ${ }^{[35]}$

Further studies involving genetic linkage assessment are needed to evaluate the direct effect of these polymorphisms on T2DM; also, the studies should be carried out on a large cohort of population. The major limitation of the current study is its moderately low sample size. While polymorphisms of the VDR gene might play a role in the pathogenesis of T2DM, the non-association of Fokl, Bsml and Taql need to be interpreted considering this limitation. Finally, our data affirms the association of VDR polymorphism in combination of genotypes with risk of T2DM in the north Indian population.

\section{ACKNOWLEDGMENTS}

The authors would like to thank the Department of Biotechnology, Govt. of India, for funding the work.

\section{REFERENCES}

1. Gragnoli C, Milord E, Habener JF. Linkage study of the glucagon receptor gene with type 2 diabetes mellitus in Italians. Metabolism 2005;54:786-7.

2. Almawi WY, Wakim-Ghorayeb SF, Arekat
MR, Najm P, Keleshian SH, Al-Sayed N, et al. Association of selective HLA class II susceptibilityconferring and protective haplotypes with type 2 diabetes in patients from Bahrain and Lebanon. Clin Vaccine Immunol 2006;13:1296-8.

3. Grarup N, Rose CS, Andersson EA, Andersen $G$, Nielsen AL, Albrechtsen A, et al. Studies of association of variants near the HHEX, CDKN2A/B, and IGF2BP2 genes with type 2 diabetes and impaired insulin release in 10,705 Danish subjects: Validation and extension of genome-wide association studies. Diabetes 2007;56:3105-11.

4. Leak TS, Mychaleckyj JC, Smith SG, Keene KL, Gordon CJ, Hicks PJ, et al. Evaluation of a SNP map of 6q24-27 confirms diabetic nephropathy loci and identifies novel associations in type 2 diabetes patients with nephropathy from an African-American population. Hum Genet 2008;124:63-71.

5. Herder C, Rathmann W, Strassburger K, Finner H, Grallert $\mathrm{H}$, Huth $\mathrm{C}$, et al. Variants of the PPARG, IGF2BP2, CDKAL1, HHEX, and TCF7L2 genes confer risk of type 2 diabetes independently of $\mathrm{BMI}$ in the German KORA studies. Horm Metab Res 2008;40:722-6.

6. Wu Y, Li H, Loos RJ, Yu Z, Ye X, Chen L, et al. Common variants in CDKAL1, CDKN2A/B, IGF2BP2, SLC30A8, and HHEX/IDE genes are associated with type 2 diabetes and impaired fasting glucose in a Chinese Han population. Diabetes 2008;57:2834-42.

7. Lee YH, Kang ES, Kim SH, Han SJ, Kim CH, Kim $\mathrm{HJ}$, et al. Association between polymorphisms in SLC30A8, HHEX, CDKN2A/B, IGF2BP2, FTO, WFS1, CDKAL1, KCNQ1 and type 2 diabetes in the Korean population. J Hum Genet 2008;53:991-8.

8. $\mathrm{Ng} \mathrm{MC,} \mathrm{Park} \mathrm{KS,} \mathrm{Oh} \mathrm{B,} \mathrm{Tam} \mathrm{CH,} \mathrm{Cho} \mathrm{YM,} \mathrm{Shin}$ $\mathrm{HD}$, et al. Implication of genetic variants near TCF7L2, SLC30A8, HHEX, CDKAL1, CDKN2A/B, IGF2BP2, and FTO in type 2 diabetes and obesity in 6,719 Asians. Diabetes 2008;57:2226-33. 
9. Tong $Y$, Lin $Y$, Zhang $Y$, Yang J, Zhang $Y$, Liu $\mathrm{H}$, et al. Association between TCF7L2 gene polymorphisms and susceptibility to type 2 diabetes mellitus: A large Human Genome Epidemiology (HuGE) review and meta-analysis. BMC Med Genet 2009;10:15.

10. Boullu-Sanchis S, Lepretre F, Hedelin G, Donnet JP, Schaffer P, Froguel P, et al. Type 2 diabetes mellitus: Association study of five candidate genes in an Indian populaton of Guadeloupe, genetic contribution of FABP2 polymorphism. Diabetes Metab (Paris) 1999;25:150-6.

11. Ruchat SM, Elks CE, Loos RJ, Vohl MC, Weisnagel SJ, Rankinen T, et al. Association between insulin secretion, insulin sensitivity and type 2 diabetes susceptibility variants identified in genome-wide association studies. Acta Diabetol 2008;Dec 10 [Epub ahead of print].

12. Groop L, Lyssenko V. Genes and type 2 diabetes mellitus. Curr Diab Rep 2008;8:192-7.

13. Osawa $H$, Yamada $K$, Onuma $H$, Murakami $A$, Ochi $\mathrm{M}$, Kawata $\mathrm{H}$, et al. The $\mathrm{G} / \mathrm{G}$ genotype of a resistin single-nucleotide polymorphism at -420 increases type 2 diabetes mellitus susceptibility by inducing promoter activity through specific binding of Sp1/3. Am J Hum Genet 2004;75:678-86.

14. Wang H, Craig RL, Schay J, Chu W, Das SK, Zhang $Z$, et al. Alpha-endosulfine, a positional and functional candidate gene for type 2 diabetes: molecular screening, association studies, and role in reduced insulin secretion. Mol Genet Metab 2004;81:9-15.

15. Elbein SC, Chu W, Ren Q, Hemphill C, Schay J, Cox NJ, et al. Role of calpain-10 gene variants in familial type 2 diabetes in Caucasians. J Clin Endocrinol Metab 2002;87:650-4.

16. Kang ES, Kim HJ, Nam M, Nam CM, Ahn CW, Cha BS, et al. A novel 111/121 diplotype in the Calpain-10 gene is associated with type 2 diabetes. J Hum Genet 2006;51:629-33.

17. Mohamed MB, Mtiraoui N, Ezzidi I, Chaieb M, Mahjoub T, Almawi WY. Association of the peroxisome proliferator-activated receptor- gamma2 Pro12Ala but not the C1431T gene variants with lower body mass index in Type 2 diabetes. J Endocrinol Invest 2007;30:937-43.

18. Li S, Li L, Li K, Qi X, Hoekema D, Liu H, et al. Association of adipose most abundant transcript 1 gene (apM1) with type 2 diabetes mellitus in a Chinese population: A meta-analysis of case-control studies. Clin Endocrinol (Oxf) 2008;68:885-9.

19. Kallio P, Tolppanen AM, Kolehmainen M, Poutanen K, Lindström J, Tuomilehto J, et al. Association of sequence variations in the gene encoding insulin-like growth factor binding protein 5 with adiponectin. Int J Obes (Lond) 2009;33:808.

20. Lepretre F, Vionnet N, Budhan S, Dina C, Powell KL, Génin E, et al. Genetic Studies of polymorphisms in ten non-insulin dependent diabetes mellitus candidate genes in Tamil Indians from Pondichery. Diabetes Metab 1998;24:244-50.

21. McDermott MF, Ramachandran A, Ogunkolade BW, Aganna E, Curtis D, Boucher BJ, et al. Allelic variation on the VDR influence susceptibility to insulin dependent diabetes mellitus in Indian Asians. Diabetolgia 1997;40:971-5.

22. Hitman GA, Mannan N, McDermott MF, Aganna E, Ogunkolade BW, Hales CN, et al. VDR gene polymorphism influence insulin secretion in Bangladeshi Asian. Diabetes 1998;47:688-91.

23. Speer G, Cseh K, Winkler G, Vargha P, Braun E, TakaÂcs I, et al. Vitamin D and estrogen receptor gene polymorphisms in type 2 diabetes mellitus and in android type obesity. Eur J Endocrinol 2001;144:385-9.

24. Calle C, Maestro B, García-Arencibia M. Genomic actions of 1,25-dihydroxyvitamin D3 on insulin receptor gene expression, insulin receptor number and insulin activity in the kidney, liver and adipose tissue of streptozotocin-induced diabetic rats. BMC Mol Biol 2008;9:65.

25. Lee S, Clark SA, Gill RK, Christakos S. 1,25-Dihydroxyvitamin D3 and pancreatic $\mathrm{D}$-cell 
function: VDRs, gene expression, and insulin secretion. Endocrinology 1994;134:1602-10.

26. Pittas AG, Lau J, Hu F, Dawson-Hughes B. The Role of Vitamin $D$ and Calcium in type 2 diabetes. A systematic Review and Meta-Analysis. J Clin Endocrinol Metab 2007;92:2017-29.

27. Knekt $P$, Laaksonen $M$, Mattila $C$, Härkänen $T$, Marniemi J, Heliövaara M, et al. Serum Vitamin D and Subsequent Occurrence of Type 2 Diabetes. Epidemiol 2008;19:666-71.

28. Filus A, Trzmiel A, Kuliezkowska-Plaksej J, Tworowska U, Jedrzejuk D, Milewiez A, et al. Relationship between VDR Bsml and Fokl polymorphism and anthropometric and biochemical parameters describing metabolic syndrome. Aging Male 2008;11:134-9.

29. Naito M, Miyaki K, Naito T, Zhang L, Hoshi K, Hara $A$, et al. Association between vitamin $D$ receptor gene haplotypes and chronic periodontitis among Japanese men. Int. J Med Sci 2007;4:216-22.

30. Whitfield GK, Remus LS, Jurutka PW, Zitzer H, Oza AK, Dang HT, et al. Functionally relevant polymorphisms in the human nuclear vitamin D receptor gene. Mol Cell Endocrinol 2001;177: 145-59.

31. American Diabetes Association. Screening for Type 2 Diabetes. Diabetes Care 2004;27:S11-S14.

32. Harris SS, Eccleshall TR, Gross C, DawsonHughes B, Feldman D. The VDR start codon polymorphism (Fok-I) and bone mineral density in premenopausal American Black and White women. J Bone Miner Res 1997;12:1043-8.

33. Morrison, NA, Qi JC, Tokita A, Kelly PJ, Crofts L, Nguyen TV, et al. Prediction of bone density from
Vitamin D receptor. Nature 1994;367:284-7.

34. Palomer X, Gonza'lez-Clemente JM, BlancoVaca F, Mauricio D. Role of vitamin D in the pathogenesis of type 2 diabetes mellitus. Diabetes Obes Metab 2008;10:185-97.

35. Malecki MT, Frey J, Moczulski D, Klupa T, Kozek E, Sieradzki J. VDR gene polymorphisms and association with type 2 diabetes mellitus in a polish population. Exp Clin Endocrinol Diabetes 2003;111:505-9.

36. Ye W, Reis AF, Dubois-Laforgue D, BellanneChantelot C, Timsit J, Velho G. VDR gene polymorphisms are associated with obesity in type 2 diabetic subjects with early age of onset. Euro J Endocrinol 2001;145:181-6.

37. Ortlepp JR, Lauscher J, Hoffmann R, Hanrath P, Joost HG. The VDR gene variant is associated with the prevalence of Type 2 diabetes mellitus and coronary artery disease. Diabet Med 2001;18:842-5.

38. Oh J, Barrett-Connor E. Association between VDR Polymorphism and Type 2 Diabetes or Metabolic Syndrome in Community-Dwelling Older Adults: The Rancho Bernardo Study. Metabolism 2002;5:356-9.

39. Cyganek K, Mirkiewicz-Sieradzka B, Malecki MT, Wolkow P, Skupien J, Bobrek J, et al. Clinical risk factors and the role of VDR gene polymorphisms in diabetic retinopathy in Polish type 2 diabetes patients. Acta Diabetol 2006;43:114-9.

Source of Support: Nil, Conflict of Interest: None declared. 